\title{
Anemia and the frailty syndrome amongst the elderly living in the community: a systematic review
}

Elisa Priscila Sousa de Assis',2

Barbara Gazolla de Macêdo,3

Hanna Sette Camara de Oliveira'

Poliana de Paula Dias Rezende ${ }^{\mathrm{l}}$

Carlos Maurício Figueiredo Antunes'

\section{Abstract}

Objective: To evaluate the association between anemia and the onset of the frailty syndrome amongst the elderly living in the community. Method: A systematic literature review of articles from the MEDLINE and LILACS databases published in English, Spanish and Portuguese over the last ten years was carried out. Articles were included in accordance with the Preferred Reporting Items for Systematic Reviews and Meta-Analyses (PRISMA) guidelines. Results: The search identified 193 studies. After deleting duplicated articles and applying the exclusion criteria only seven articles remained. Three articles used standardized criteria to define frailty, whereas four evaluated functional capacity as a synonym for the frailty syndrome. Conclusion: Anemia was related to a worsening of functional capacity and to the presence of the frailty syndrome in elderly persons living in the community. However, the risk of bias in the studies was high in relation to the selection of the criteria and instruments used to assess and define frailty.

\footnotetext{
Instituto de Ensino e Pesquisa da Santa Casa de Belo Horizonte, Programa de Pós-graduação Stricto Sensu em Medicina e Biomedicina, Laboratório de Epidemiologia. Belo Horizonte, Minas Gerais, Brasil.

2 Fundação Hospitalar do Estado de Minas Gerais (FHEMIG), Hospital Regional de Barbacena Dr. José Américo, Fisioterapia Respiratória. Barbacena, Minas Gerais, Brasil.

3 Instituto da Previdência dos Servidores do Estado de Minas Gerais (IPSEMG), Departamento de Fisioterapia. Belo Horizonte, Minas Gerais, Brasil.

Research funding: National Council for Scientific and Technological Development (CNPq) (CMFA - 1A Research Grant) and Research Support Foundation of the State of Minas Gerais (FAPEMIG) (Projeto CDSAPQ-0078415).
}

Keywords: Anemia. Frayl Elderly. Sarcopenia. Muscle Strength. Wallking Speed. 


\section{INTRODUCTION}

Aging is accompanied by physiological factors that can cause reduced functional capacity. When combined with chronic degenerative diseases, functional dependence can be a determinant for the deterioration of quality of life ${ }^{1,2}$. The gastrointestinal system and bone marrow also suffer during aging, leading to a greater frequency of anemia in this population ${ }^{1}$.

According to the World Health Organization, anemia is defined as a concentration of hemoglobin of $<120 \mathrm{~g} / 1$ for women and $<130 \mathrm{~g} / 1$ for $\mathrm{men}^{3}$. The prevalence of anemia increases with age and has been reported in more than $20 \%$ of elderly persons aged 85 years or more, over $10 \%$ of elderly persons living in the community and in around $50 \%$ of institutionalized elderly persons ${ }^{4}$. The reduction of hemoglobin may be due to nutritional deficiency, chronic inflammation or unexplained factors ${ }^{5}$. Anemia is associated with reduced mobility, cognitive ability and quality of life and increased mortality. Some studies have associated the reduction of hemoglobin levels with the development of the frailty syndrome $e^{6,7}$.

Frailty is a clinical syndrome that leads to multisystem decline and reduced energy reserves and homeostatic balancing ability following a destabilizing event. It is multifactorial and associated with immunosenescence and inflammatory processes $^{3,8}$. Immunosenescence is accompanied by dysregulation of the immune system and an increase in the production of inflammatory cytokines (IL-6, TNF-alpha, IL-1), producing a chronic low-grade inflammatory state. The mechanism by which the increase of inflammatory cytokines leads to the development of the frailty syndrome is still uncertain, but evidence indicates the catabolic action of this mediator?. The criteria that define frailty are controversial; the most used are decreased muscle strength, exhaustion, reduced gait speed, reduced physical activity and unintentional weight loss ${ }^{9}$. However, some authors suggest the inclusion of other criteria such as nutrition, comorbidities and socioeconomic aspects ${ }^{3,8}$. The establishment of precise criteria and the standardization of instruments that evaluate frailty are important for the diagnosis of the condition and for preventive interventions that can delay or prevent the progression of the syndrome, preserving functional independence for longer ${ }^{10,11}$.

The probable association between the frailty syndrome and anemia is of great importance to the area of geriatrics, as these are common phenomena in this population and when combined may present a more serious clinical outcome ${ }^{3}$.

The aim of this study was to evaluate, through a systematic literature review, the association between anemia and the frailty syndrome in elderly persons living in the community.

\section{METHOD}

The literature review used the MEDLINE and LILACS databases to search for articles in English, Spanish and Portuguese. As the concept of frailty has been established in literature in the last decade, the review was limited to publications from the last 10 years . The selected descriptors were: frail, elderly, anemia, sarcopenia, motor activity, muscle strength, mobility limitation, walking. Articles with the key words in the titles or abstracts and published by September 2016 were sought. The search strategy and the Boolean descriptors and operators was as follows:

tw: [anemia AND ("Capacidade funcional" OR funcionalidade OR "Independencia funcional" OR "Atividade funcional" OR "capacidad funcional" OR funcionalidad OR "independencia funcional" OR "actividad funcional" OR "Functional capacity" OR functionality OR "functional independence" OR "functional activity" OR sarcopenia OR "Motor Activity" OR "Actividad Motora" OR "Atividade Motora" OR "Muscle Strength" OR "Fuerza Muscular" OR "Força Muscular" OR "Mobility Limitation" OR "Limitación de la Movilidad" OR "Limitação da Mobilidade" OR "walking" OR "caminata" OR "caminhada" OR "frail elderly")] AND (instance:"regional") AND [limit:("aged") AND la: ("en" OR "es" OR "pt") AND year_ cluster:("2013" OR "2014" OR "2009" OR "2008" OR "2012" OR "2015" OR "2007" OR "2010" OR "2006" OR "2011" OR "2016")]. 
Observational-type studies addressing anemia, frailty and/or functional capacity in the elderly living in the community were adopted as inclusion criteria. Articles that approached hospitalized or institutionalized elderly people undergoing cancer treatment in the postoperative period and with serious diseases such as rheumatologic, renal, cardiac and pulmonary insufficiency, were excluded. The selection and qualification of articles were carried out by two independent reviewers following the inclusion criteria. In the case of disagreement, the articles were read and discussed together. The review followed the specific methodological guidelines for observational studies ${ }^{12}$. To select the data of the articles, the Preferred Reporting Items for Systematic Reviews and MetaAnalyzes (PRISMA) criteria were applied, and for the analysis of the selected articles an instrument was elaborated based on the population, exposure/ intervention, control and outcome (PECO) domains ${ }^{13}$.

The assessment of the risk of bias in the articles included in the analysis was performed using an adapted version of the Newcastle-Ottawa Scale (Chart 1). The original scale evaluates the quality of observational studies and contains eight items that analyze three dimensions, with several options for each item. In this review, the questions were adjusted to investigate exposure and outcome (frailty syndrome), and the risk of bias was divided as follows: low, uncertain, and high risk ${ }^{14}$.

This review was registered with the International Prospective Register of Systematic Review (PROSPERO) under number CRD42017057567.

Chart 1. Adaptation of Newcastle-Ottawa Scale for evaluation of quality of studies. Belo Horizonte, Minas Gerais, 2017.

\begin{tabular}{|c|c|}
\hline Exposure & a) Secure record + primary measures $*$ (low risk of bias) \\
\hline \multirow[t]{4}{*}{ Obtaining the independent variables } & $\begin{array}{l}\text { b) Structured interview }+ \text { primary measures, without knowledge of the } \\
\text { outcome } * \text { (low risk of bias) }\end{array}$ \\
\hline & c) Interview with knowledge of the outcome (high risk of bias) \\
\hline & d) Non-secure sources and self-assessment (high risk of bias) \\
\hline & e) Does not describe clearly (uncertain risk of bias) \\
\hline \multicolumn{2}{|l|}{ Outcome } \\
\hline \multirow[t]{4}{*}{ Is the assessment of frailty adequate? } & a) Yes, (low risk of bias) \\
\hline & $\begin{array}{l}\text { b) Yes, according to Fried et al. with some modifications ( } 2 \text { or } 1 \text { components) } \\
\text { (uncertain risk of bias) }\end{array}$ \\
\hline & $\begin{array}{l}\text { c) Yes, according to Fried et al., with many modifications ( } 3 \text { or more } \\
\text { components) (high risk of bias) }\end{array}$ \\
\hline & d) No, describes as functional capacity (high risk of bias) \\
\hline \multirow[t]{3}{*}{ Sample representativeness } & a) Representative of the local population * (low risk of bias) \\
\hline & b) Possibility of selection bias (high risk of bias) \\
\hline & c) Does not clearly describe (uncertain risk of bias) \\
\hline \multirow[t]{2}{*}{ Selection of participants } & a) Community $*$ (low risk of bias) \\
\hline & b) Does not clearly describe (uncertain risk of bias) \\
\hline \multirow[t]{2}{*}{ Definition of the control group } & a) No previous history of the syndrome * (low risk of bias) \\
\hline & b) Does not clearly describe (uncertain risk of bias) \\
\hline
\end{tabular}

* Represents an item with the classification of low risk of bias. 


\section{RESULTS}

This review identified 193 articles in the Medline (96) and Lilacs (97) databases. After the elimination of eight duplicate articles, 32 articles were selected according to the inclusion criteria. Of the 32 eligible articles, 25 were excluded for being review articles, clinical trials, or treatment and other studies where frailty was not the primary outcome. In the end, only seven studies met all the inclusion criteria.

Figure 1 shows the flow chart of the identification and selection of articles for the systematic review.

The descriptions and evaluations of the selected studies are presented in Charts 2 and 3. The articles were separated according to the definitions of the frailty syndrome employed.

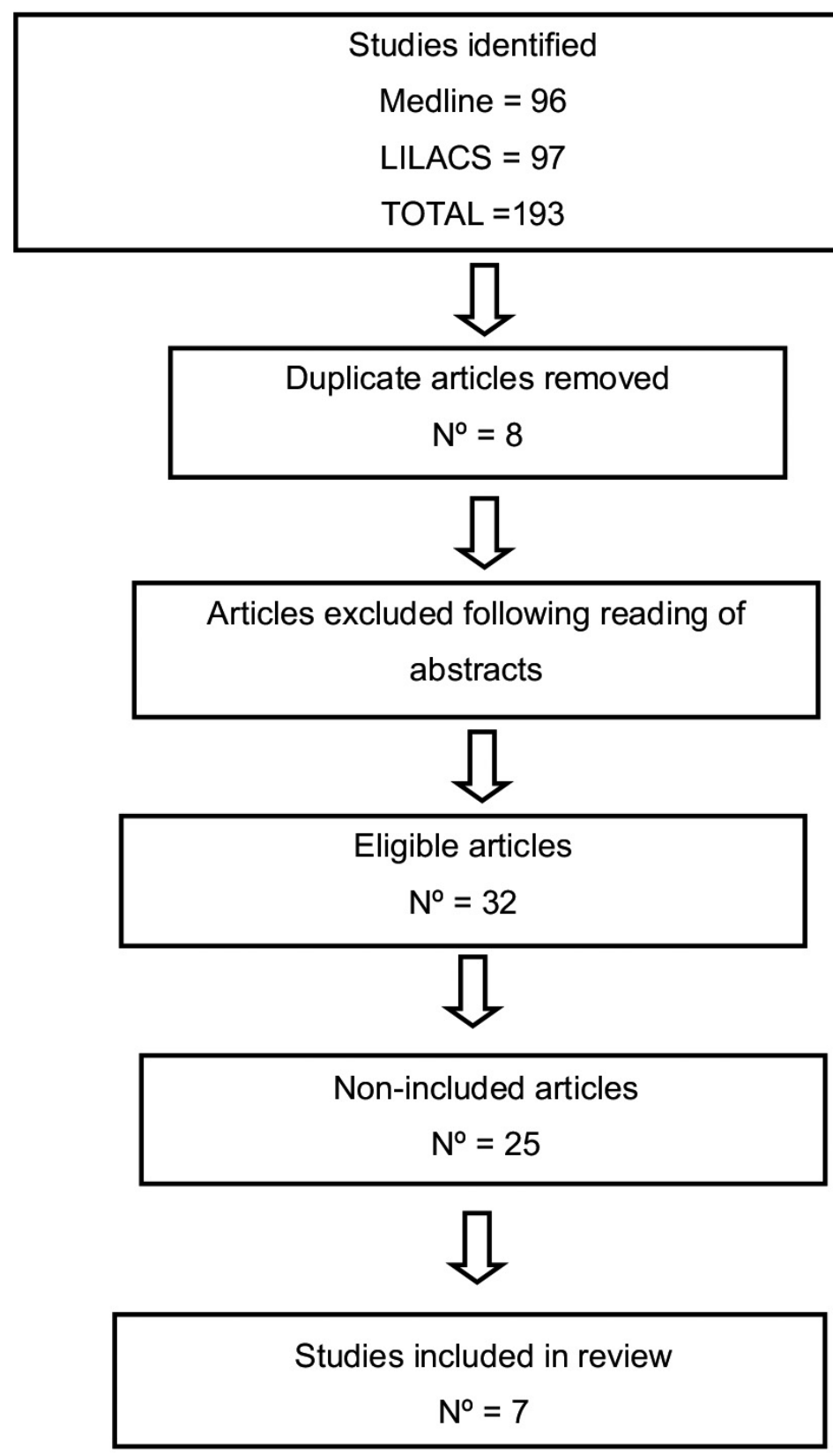

Figure 1. Flowchart of phases of review in accordance with PRISMA criteria. Belo Horizonte, Minas Gerais, 2017. 
Chart 2. Anemia and Frailty Syndrome (defined criteria). Belo Horizonte, Minas Gerais, 2017.

\begin{tabular}{|c|c|c|c|c|}
\hline Author(s) & Type and objective of study & $\begin{array}{l}\text { Participants and } \\
\text { measure of frailty }\end{array}$ & Result & Outcome \\
\hline $\begin{array}{l}\text { Corona } \\
\text { et al. } \\
(2014)\end{array}$ & $\begin{array}{l}\text { Cross-sectional study based } \\
\text { on SABE. } \\
\text { The objective was to evaluate } \\
\text { the association between } \\
\text { anemia, hemoglobin and } \\
\text { frailty. }\end{array}$ & $\begin{array}{l}1345 \text { participants. } \\
\text { Complete frailty } \\
\text { criteria (Fried) not } \\
\text { used. }\end{array}$ & $\begin{array}{l}2.5 \text {-fold increase in } \\
\text { probability of frailty. } \\
12 \mathrm{mg} / \mathrm{dlHb}=30 \% . \\
\text { Women }=25 \% . \\
14 \mathrm{mg} / \mathrm{dlHb} \text {. Frailty: } \\
\text { men }=10 \% \text { and } \\
\text { women }<10 \% .\end{array}$ & $\begin{array}{l}\text { Positive association } \\
\text { between anemia } \\
\text { and frailty. }\end{array}$ \\
\hline $\begin{array}{l}\text { Silva et al. } \\
(2014)\end{array}$ & $\begin{array}{l}\text { Cross-sectional study based } \\
\text { on FIBER. } \\
\text { The objective was to evaluate } \\
\text { the association between } \\
\text { frailty, inflammatory markers } \\
\text { and hemoglobin. }\end{array}$ & $\begin{array}{l}255 \text { participants. } \\
\text { Frailty assessed with } \\
\text { WHAS criteria. }\end{array}$ & $\begin{array}{l}\text { Reduction of } \\
\text { hemoglobin } \\
\text { associated with } \\
\text { frailty, sarcopenia, } \\
\text { and weight loss. }\end{array}$ & $\begin{array}{l}\text { Positive for the } \\
\text { association between } \\
\text { anemia and frailty } \\
\text { in women. }\end{array}$ \\
\hline $\begin{array}{l}\text { Llibre et } \\
\text { al. } \\
(2014)\end{array}$ & $\begin{array}{l}\text { Longitudinal study based on } \\
\text { the Cuban cohort. } \\
\text { The objective was to identify } \\
\text { the prevalence and incidence } \\
\text { of frailty, risk factors (anemia) } \\
\text { and incidence of functional } \\
\text { dependence. }\end{array}$ & $\begin{array}{l}2813 \text { participants. } \\
\text { Frailty criteria (Fried) } \\
\text { were modified. }\end{array}$ & $\begin{array}{l}\text { Greater frailty in } \\
\text { women (educational } \\
\text { level and marital } \\
\text { status as protective } \\
\text { factor for frailty). }\end{array}$ & $\begin{array}{l}\text { Anemia as a risk } \\
\text { factor for the } \\
\text { prevalence of frailty } \\
\text { (prevalence rate of } \\
1.64 \% \text { - CI }(1.23- \\
2.20) \text {. }\end{array}$ \\
\hline
\end{tabular}

Chart 3. Anemia and functional capacity. Belo Horizonte, Minas Gerais, 2017.

\begin{tabular}{|c|c|c|c|c|}
\hline Author(s) & Type of study and objective & $\begin{array}{l}\text { Participants and measure } \\
\text { of functional capacity }\end{array}$ & Results & Outcome \\
\hline $\begin{array}{l}\text { Patel et al. } \\
(2007)\end{array}$ & $\begin{array}{l}\text { Longitudinal study based } \\
\text { on } 15 \% \text { of the cohort } \\
\text { Health Aging and Body } \\
\text { compositional study (ABC). } \\
\text { The objective was to check } \\
\text { whether functional changes } \\
\text { varied in the presence of } \\
\text { anemia among black and } \\
\text { white skinned persons, } \\
\text { and to observe differences } \\
\text { between cut-off points for } \\
\text { anemia. }\end{array}$ & $\begin{array}{l}2,601 \text { participants. } \\
\text { Evaluation of mobility } \\
\text { through self-reporting. } \\
\text { Functional changes: } \\
\text { walking, climbing stairs } \\
\text { and activities of daily } \\
\text { living. }\end{array}$ & $\begin{array}{l}\text { Hemoglobin levels } \\
\text { vary according } \\
\text { to skin color/ } \\
\text { ethnicity. }\end{array}$ & $\begin{array}{l}\text { The presence of } \\
\text { anemia is associated } \\
\text { with a higher risk } \\
\text { ( } 2 \text { to } 3 \text { times) of } \\
\text { mortality and } \\
\text { functional disability } \\
\text { in white elderly } \\
\text { persons. In black } \\
\text { elderly persons } \\
\text { functional capacity } \\
\text { is greater, suggesting } \\
\text { that the cut-off point } \\
\text { for this group should } \\
\text { be lower. }\end{array}$ \\
\hline
\end{tabular}


Continuation of Chart 3

\begin{tabular}{|c|c|c|c|c|}
\hline Author(s) & Type of study and objective & $\begin{array}{l}\text { Participants and measure } \\
\text { of functional capacity }\end{array}$ & Results & Outcome \\
\hline $\begin{array}{l}\text { Haslamet } \\
\text { et al. } \\
(2012)\end{array}$ & $\begin{array}{l}\text { Cross-sectional study based } \\
\text { on the Georgia Centenarian } \\
\text { Study (GCS). } \\
\text { The objective was to evaluate } \\
\text { the association between } \\
\text { anemia and functional } \\
\text { capacity in elderly people. }\end{array}$ & $\begin{array}{l}244 \text { participants. } \\
\text { Physical function } \\
\text { measured through } \\
\text { handgrip strength } \\
\text { and knee extension, } \\
\text { instrumental activities of } \\
\text { daily living (SPPB). }\end{array}$ & $\begin{array}{l}\text { Centenarian } \\
\text { elderly persons } \\
\text { with anemia } \\
\text { exhibited greater } \\
\text { loss of muscle } \\
\text { strength, but there } \\
\text { was no difference } \\
\text { in activities of } \\
\text { daily living. The } \\
\text { sample was not } \\
\text { described. High } \\
\text { mortality rate } \\
\text { among elderly } \\
\text { people. }\end{array}$ & $\begin{array}{l}\text { Anemic centenarian } \\
\text { elderly persons } \\
\text { exhibited a reduction } \\
\text { in grip and lower } \\
\text { limb strength } \\
\text { with no impact on } \\
\text { activities of daily } \\
\text { living. }\end{array}$ \\
\hline $\begin{array}{l}\text { Contreras } \\
\text { et al. } \\
(2015)\end{array}$ & $\begin{array}{l}\text { Longitudinal study based on } \\
\text { Octabaix cohort. } \\
\text { The objective was to analyze } \\
\text { the prevalence of anemia } \\
\text { in the elderly and the } \\
\text { association with mortality } \\
\text { after } 3 \text { years of follow-up. }\end{array}$ & $\begin{array}{l}328 \text { participants. } \\
\text { Tests used: Barthel, } \\
\text { Lawton, Tinetti scale - } \\
\text { POMA. }\end{array}$ & $\begin{array}{l}\text { Higher mortality } \\
\text { in anemic elderly } \\
\text { persons, who } \\
\text { had a worse } \\
\text { perception of } \\
\text { quality of life. }\end{array}$ & $\begin{array}{l}\text { Higher mortality } \\
\text { in anemic elderly, } \\
\text { who had a worse } \\
\text { perception of quality } \\
\text { of life. Presence } \\
\text { of an association } \\
\text { between anemia and } \\
\text { physical function. }\end{array}$ \\
\hline $\begin{array}{l}\text { Liu et al. } \\
(2015)\end{array}$ & $\begin{array}{l}\text { Cross-sectional study based } \\
\text { on Rugão cohort. } \\
\text { The objective was to evaluate } \\
\text { the association between } \\
\text { anemia and mortality in } \\
\text { elderly individuals aged } 95 \\
\text { years or older. }\end{array}$ & $\begin{array}{l}435 \text { participants. } \\
\text { Tests: basic and } \\
\text { instrumental activities } \\
\text { of daily living, squatting, } \\
\text { ability to raise hands } \\
\text { above head level. Non- } \\
\text { detailed evaluation tools. }\end{array}$ & $\begin{array}{l}\text { Anemia associated } \\
\text { with all causes of } \\
\text { mortality. Women } \\
\text { with anemia were } \\
\text { more physically } \\
\text { dependent than } \\
\text { men. }\end{array}$ & $\begin{array}{l}\text { Presence of } \\
\text { association between } \\
\text { anemia and physical } \\
\text { function. }\end{array}$ \\
\hline
\end{tabular}

The concepts and criteria of the frailty syndrome diverged between the studies. Of the seven articles included, three used standardized criteria for the definition of frailty ${ }^{15-17}$ while four studies evaluated functional capacity as a synonym for frailty syndrome $e^{18-21}$.

The review found a consensus that anemia is independently related to worsening functional capacity and frailty syndrome. However, there was great variability in relation to the criteria and instruments used for functional evaluation and characterization of this syndrome.

\section{DISCUSSION}

Despite the importance of the theme, this systematic review identified few studies that related anemia and the frailty syndrome in elderly persons living the community.

All seven observational articles that were included in this systematic review found an association between anemia and the development of frailty or the worsening of functional capacity. However, a high risk of bias in the evaluation and definition of the frailty syndrome was found by the adapted Newcastle- 
Ottawa scale. Of the seven studies included, only one presented a low risk of bias in the evaluation criterion for the identification of this syndrome. This fact is explained by the variety and non-standardization of the criteria and instruments used to define frailty and may limit the interpretation of the association between anemia and this syndrome (Chart 4). Another important issue is the fact that many authors consider functional capacity and frailty to be synonyms, even though both can occur in isolation ${ }^{18-21}$.

Chart 4. Assessment of bias risk according to the adaptation of the Newcastle-Ottawa Scale. Belo Horizonte, Minas Gerais, 2017.

\begin{tabular}{|l|l|l|l|l|l|}
\hline $\begin{array}{l}\text { Article } \\
\text { (year) }\end{array}$ & $\begin{array}{l}\text { Obtaining the } \\
\text { independent } \\
\text { variables }\end{array}$ & $\begin{array}{l}\text { Evaluation of } \\
\text { frailty }\end{array}$ & $\begin{array}{l}\text { Representativeness } \\
\text { of samples }\end{array}$ & $\begin{array}{l}\text { Selection of } \\
\text { participants }\end{array}$ & $\begin{array}{l}\text { Definition of } \\
\text { the control } \\
\text { group or cohort }\end{array}$ \\
\hline Corona et al. (2014) & U & H & U & L & - \\
\hline Silva et al.(2014) & U & L & U & L & - \\
\hline Llibre et al.(2014) & L & U & U & L & L \\
\hline Patel et al.(2007) & L & H & U & L & L \\
\hline Haslamet et al. (2012) & U & H & U & L & - \\
\hline Contreras et al.(2015) & L & H & U & L & L \\
\hline Liu et al(2015) & U & H & U & L & - \\
\hline
\end{tabular}

Classification of items: H - high risk of bias; B - low risk of bias; I - uncertain risk of bias.

The study conducted by Corona et al. ${ }^{15}$ evaluated the association between anemia, hemoglobin and the frailty syndrome. Anemic individuals were 2.5 times more likely to develop frailty. However, the criteria proposed by Fried were not fully complied with ${ }^{15}$. The study from the FIBRA network, meanwhile, identified a relationship between hemoglobin reduction, frailty, sarcopenia and weight loss, using the Women's Health and Aging Study (WHAS) criteria for frailty ${ }^{16}$.

In a sample of 2813 Cuban elderly persons the assessment of cognitive status was added to the frailty criteria proposed by Fried. Anemia was an important risk factor for the prevalence of frailty (a prevalence rate of $1.64 \%$ (Confidence Interval $1.23-2.20))^{17}$.

In a longitudinal study of 2,601 elderly people, Patel et al. evaluated whether functional changes (walking, climbing stairs and activities of daily living) varied in the presence of anemia among black and white skinned people. A decline in functional performance was observed in the presence of anemia. Considering the cutoff point for anemia proposed by the WHO, white anemic elderly individuals presented more functional alterations than black elderly persons. The results suggest adaptations to the cutoff point for the diagnosis of anemia specific for each skin color $^{18}$.

A longitudinal study with three years of follow-up assessment evaluated functional capacity in anemic elderly persons using the Barthel and Lawton Indexes and the Performance Oriented Mobility Assessment (POMA). The authors found a higher mortality rate and worse perception of quality of life and functional capacity in anemic elderly persons ${ }^{19}$.

Two studies with centenarian elderly persons found an association between anemia and the decline of functional capacity. The studies used different assessment instruments and did not define the criteria for the frailty syndrome ${ }^{20,21}$. The number of nonagenarian or older elderly persons is increasing rapidly around the world, but longitudinal studies in this age group are rare due to the greater number of comorbidities and a high mortality rate re,21. $^{20}$

Decreased functional capacity in the elderly can be associated with numerous multidimensional 
factors which determine the degree of dependence of the population and can lead to frailty. Various instruments exist for the measurement of muscle strength, balance, activities, and instruments of daily living. The studies in this review present tests and instruments for assessing functional capacity, such as the Lawton scale and the step climbing, gait speed, squat, handgrip and lower limb strength and balance tests, and the Short Physical Performance Battery (SPPB).

The frailty syndrome is complex and involves deterioration in multiple physiological domains, including strength and muscle mass, flexibility, balance, coordination and cardiovascular function ${ }^{22}$. The inclusion of other criteria for the definition of frailty syndrome, such as socioeconomic factors, nutritional factors and comorbidities, such as the presence of anemia, has been previously discussed ${ }^{23}$. However, there is still no explicit agreement as to how to diagnose the syndrome or an instrument to assist in the prior identification of adverse events. The model most widely used around the world is that proposed by Fried et al. It is composed of five biological items: unintentional weight loss in the last year, reduced handgrip strength, slow gait, exhaustion and low physical activity. Elderly persons are considered frail when they present three or more of these criteria ${ }^{10}$. Therefore, the lack of a conceptual and methodological criterion to define a frail elderly persons makes it difficult to evaluate and compare the studies evaluated.

Only one study of this review associated the increase of inflammatory markers, the presence of anemia and the frailty syndrome ${ }^{16}$. The inflammatory state is part of the immunosenescence process and is directly related to age. This process is characterized by an increase in inflammatory cytokines such as IL-6, IL-1, TNF-alpha and IFN-gamma. These cytokines are directly related to increasing age and the development of inflammatory anemia. Anemia and the frailty syndrome may share this pathophysiological mechanism of the inflammation process, and so anemia may trigger the frailty syndrome and vice versa ${ }^{23,24}$.

\section{CONCLUSION}

Anemia was related to a decline in functional capacity and to the presence of the frailty syndrome in the elderly persons living in the community. However, the definition and criteria used to assess frailty differed between studies, and caution is required in the interpretation of these results.

The heterogeneity of the studies makes it difficult to verify evidence and generalize the data of the association between anemia and the frailty syndrome in elderly residents of the community.

New studies should be carried out with greater methodological rigor and standardization of the instruments and criteria used to allow a statistical comparison between anemia and frailty.

Early identification of anemic and/or frail elders will allow interventions to prevent or delay the "anemiafrailty" interaction, leading to an improvement in the quality of life of these elderly people.

\section{REFERENCES}

1. Brasil. Ministério da Saúde, Secretaria de Atenção à Saúde. Envelhecimento e saúde da pessoa idosa. Brasília, DF: MS; 2007. (Série A . Normas e Manuais Técnicos); (Cadernos de Atenção Básica, n. 19).

2. Küchemann BA. Envelhecimento populacional, cuidado e cidadania: velhos dilemas e novos desafios. Soc Estado. 2012;27(1):165-80.

3. Röhrig G . Anemia in the frail, elderly patient. Clin Interv Aging. 2016;11:319-26.

4. Gualandro SFM, Hojaij NHSL, Jacob Filho W. Deficiência de ferro no idoso. Rev Bras Hematol Hemoter. 2010;32(2):57-61.

5. Roy CN. Anemia in frailty. Clin Geriatr Med. 2011;27(1):67-78. 
6. Artz AS. Anemia and the frail elderly. Semin hematol. 2008;45(4):261-6.

7. Thein M, Ershler WB, Artz AS, Tecson J, Robinson BE, RothsteinG, et al. Diminished quality of life and physical function in community-dwelling elderly with anemia. Medicine. 2009;88(2):107-14.

8. Ng TP, Feng L, Nyunt MSZ, Larbi A, Yap KB. Frailty in older persons: multisystem risk factors and the Frailty Risk Index (FRI). J Am Med Dir Assoc. 2014;15(9):635-42.

9. 9. Kanapuru B, Ershler WB. Inflammation, coagulation, and the pathway to frailty. Am J Med. 2009;122(7):605-13.

10. Fried LP, Tangen CM, Walston J, Newman AB, Hirsch C, Gottdiener J, et al. Frailty in older adults: evidence for a phenotype. J Gerontol Ser A Biol Sci Med Sci. 2001;56(3):146-56.

11. Arantes PMM, Alencar MA, Dias RC, Dias JMD, Pereira LSM. Atuação da fisioterapia na síndrome de fragilidade: revisão sistemática. Rev Bras Fisioter. 2009;13(5):365-75

12. Brasil. Ministério da Saúde, Secretaria de Ciência, Tecnologia e Insumos Estratégicos, Departamento de Ciência e Tecnologia. Diretrizes metodológicas elaboração de revisão sistemática e metanálise de ensaios clínicos randomizados. Brasília, DF: MS; 2012.

13. Moher D, Liberati A, Tetzlaff J, Altman DG; PRISMA Group. Preferred reporting items for systematic reviews and meta-analyses: the PRISMA statement. PloS Med. 2009;6(7):1-6.

14. Wells GA, Shea B, O'Connell D, Peterson J, Welch V, Losos M, et al. The Newcastle-Ottawa Scale (NOS) for assessing the quality of nonrandomized studies in meta- analyses. [201?] [acesso em 02 abr. 2017]. In: Ottawa Hospital Research Institute [Internet]. Ottawa: OHRI; 2001- . [1 tela]. Disponível em: http://www. ohri.ca/programs/clinical_epidemiology/oxford.asp

15. Corona LP, Drumond AFC, Oliveira Duarte YA, Lebrao ML. The relationship between anemia, hemoglobin concentration and frailty in brazilian older adults. J Nutr Health Aging. 2015;19(9):935-40.
16. Silva JC, Moraes ZV, Silva C, Mazon SB, Guariento $\mathrm{ME}$, Neri AL, et al. Understanding red blood cell parameters in the context of the frailty phenotype: interpretations of the FIBRA (Frailty in Brazilian Seniors) study. Arch Gerontol Geriatr. 2014;59(3):636-41.

17. Llibre JJ, López AM, Valhuerdi A, Guerra M, LlibreGuerra JJ, Sánchez YY, et al. Frailty, dependency and mortality predictors in a cohort of Cuban older adults, 2003-2011. MEDICC Rev. 2014;16(1):24-30.

18. Patel KV, Harris TB, Faulhaber M, Angleman SB, Connelly S, Bauer DC, et al. Racial variation in the relationship of anemia with mortality and mobility disability among older adults. Blood. 2007;109(11):4663-70.

19. Contreras MM, Formiga F, Ferrer A, Chivite D, Padrós G, Montero A, et al. Perfil y pronóstico del paciente con anemia mayor de 85 años que vive en la comunidad. Rev Esp Geriatr Gerontol. 2015;50(5):211-5.

20. Haslam A, Hausman DB, Davey A, Cress ME, Johnson MA, Poon LW, et al. Associations of anemia and physical function in Georgia centenarians. J Am Geriatr Soc. 2012;60(12):2362-63.

21. Liu ZY, Deng W, Zhang RY, Huang JP, Wang XF, Qian DG, et al. Anemia, physical function, and mortality in long-lived individuals aged 95 and older: a population-based study. J Am Geriatr Soc. 2015;63(10):2202-4.

22. Morley JE, Vellas B, Kan AV, Anker SD, Bauer JM, Bernabei R, et al. Frailty Consensus: a call to action. J Am Med Dir Assoc. 2013;14(6):392-7.

23. Ciegg A, Young J, Liffe S, Rikkert MO, Rockwood K. Frailty in older people. Lancet. 2013;381(9868):752-62.

24. Felicio DC, Pereira DS, Assumpção AM, Jesus- Moraleida FR, Queiroz BZ, Silva JP, et al. Inflammatory mediators, muscle and functional performance of community-dwelling elderly women. Arch Gerontol Geriatr. 2014;59(3):549-53. 